Palimpsesto Vol. 10, $\mathrm{N}^{\mathrm{o}} 17$ (enero-junio, 2020): 156-179

Universidad de Santiago de Chile, ISSN 0718-5898

Ana Davis González

Universidad de Sevilla

adavis@us.es

\title{
El meridiano hispano-católico argentino de la década del treinta
}

\author{
The Hispanic-Catholic Meridian of Argentina in the 1930s
}

\begin{abstract}
Resumen
El presente trabajo describe el campo intelectual argentino entre 1930 y 1945 a partir de la noción de red (Maíz, 2011), un concepto que vislumbra los intercambios dialógicos de una determinada época a través de la prensa, epistolario y paratextos. Mediante las redes de comunicación periodística, exhibiremos las polémicas desatadas, sobre todo, entre las páginas de Sur y Criterio. El fin último es demostrar cómo la primera revista posee la legitimidad literaria, mientras que la segunda es una evidencia de un nacionalismo que se torna hegemónico con el peronismo a partir de 1943. En suma, se lleva a cabo una radiografía de los debates en torno a la identidad, cultura y nacionalismo en la prensa argentina entre 1930 y 1945.
\end{abstract}

Palabras claves: redes, meridiano, campo intelectual, patria, mito de la nación católica.

\begin{abstract}
The following paper describes the Argentine intellectual field between 1930 and 1945 from the notion of network (Maíz, 2011), a concept that envisages dialogical exchanges of a certain era through the press, epistolary and paratexts. Through the networks of journalistic communication, we will exhibit the controversies unleashed between the pages of Sur and Criterio. Our goal is to demonstrate how the first magazine has literary legitimacy, while the second one is evidence of nationalist hegemony that crystallizes in Peronism from 1943. In short, we offer an x-ray of the debates around the identity, culture and nationalism in the Argentine press between 1930 and 1945.
\end{abstract}

Keywords: Networks, meridiano, intellectual field, nation, the mith of the catholic nation. 


\section{Introducción}

La polémica del meridiano fue una batalla intelectual entre hispanoamericanos y españoles a raíz del artículo "Madrid, meridiano intelectual de Hispanoamérica" (La Gaceta Literaria, 1927, $\mathrm{n}^{\mathrm{o}}$ 8) donde Guillermo de Torre ubicaba el meridiano cultural hispánico en la capital española. El texto genera una serie de reacciones por parte de los hispanoamericanos, quienes reivindican su propio meridiano nacional. En Argentina responden a los españoles, desde la revista Martín Fierro, Leopoldo Marechal, Pablo Rojas Paz, Scalabrini Ortiz, Francisco Luis Bernárdez, Jorge Luis Borges, Nicolás Olivari, Eduardo González Lanuza, Evar Méndez, entre otros. La mayoría de ellos niega su vinculación cultural a España argumentando que la tradición argentina, a pesar de su escasa historia, tiene potencial de futuro independiente de España. En 1928, la revista Nosotros ( $\mathrm{n}^{\mathrm{o}}$ 225-226) se une a los martinfierritas con una serie de respuestas, entre las cuales se halla una carta abierta de Leopoldo Lugones, quien reflexiona: "Pienso que esa cuestión de meridiano es una frivolidad sin trascendencia: aunque en lo referente al caso con España estoy con los de Martín Fierro, salva la virulencia contra dicha nación. España no nos orienta intelectualmente" (Alemany, 1998, p.145).

Las reacciones negativas por parte de los martinfierristas no sorprenden, al ser un movimiento de vanguardia que busca desligarse de toda tradición anterior -la cultura hispánica en este caso-. No obstante, sí resulta curiosa la defensa de Lugones, un escritor de la generación anterior, a quien los propios martinfierristas acusaban de poeta a la antigua ${ }^{1}$. Ante la invectiva de La Gaceta, Lugones defiende la postura nacionalista de quienes anteriormente lo había desdeñado, una actitud que da a conocer algunos cambios significativos del campo literario argentino a lo largo de la década del veinte. Como es sabido, Lugones perteneció a un grupo de intelectuales nacionalistas -la denominada Generación del Centenario-, junto a Manuel Gálvez y Ricardo Rojas, quienes buscaban definir la nación en torno a su primer aniversario. Su objetivo patriótico se conciliaba con la defensa de la tradición hispánica, en consonancia con el arielismo de Enrique Rodó. Siendo Lugones el principal exponente del modernismo en Argentina, ¿no sería más lógica una respuesta que conciliara nacionalismo, hispanoamericanismo e hispanismo? El posicionamiento de Lugones junto a los martinfierristas demuestra que el nacionalismo expuesto en la polémica abarcaba a una heterogeneidad de intelectuales: los jóvenes beligerantes de la vanguardia -detractores del sentimiento patriótico- junto a figuras que representan el nacionalismo de corte arielista. ¿A qué se debe la particularidad del Meridiano? A que anticipa, ya a finales de los años veinte, un cambio de época, una transformación de las formaciones discursivas del campo literario que se traducen en la clausura inminente de la revista Martín Fierro (1927), pero que no se deja ver con más evidencia hasta la Década Infame (1930-1943). En las páginas que siguen, intentaremos dar cuenta de tales cambios a partir de la noción de "red" (Maíz, 2011), esto es, una serie de individuos unidos entre sí por diálogos e intercambios constantes de ideas en torno a una producción cultural determinada. En primer lugar, se definirá dicho concepto para mostrar cómo ciertos discursos y materiales son apropiados de manera consciente e inconsciente por parte de sujetos culturales -intelectuales y artistas-. A continuación, aplicaremos el término a la polémica del meridiano intelectual y su evolución durante la Década Infame argentina para demostrar que, como indica Pablo Sánchez, el

${ }^{1}$ Concretamente, en los artículos de Leopoldo Marechal: "Retruque a Leopoldo Lugones" (Martín Fierro, no26, 1925) y "Filípica a Lugones y a otras especies de anteayer" (Martín Fierro, n³2, 1926). 
meridiano no fue únicamente un fenómeno de vanguardia, ni se redujo a meros insultos o reprimendas, pues:

...la cuestión en juego era ni más ni menos que la influencia de un sistema literario sobre otro, tema que no era en absoluto desdeñable en esos años porque afectaba a las identidades culturales creadas desde la emancipación de las colonias en el siglo XIX y a la autoafirmación de los escritores en el periodo vanguardista. (2018, p.41)

La Polémica se concibe en el presente estudio como una tensión cultural continua entre España e Hispanoamérica vinculada a la expresión "geopolítica del conocimiento". El término, propuesto por Walter Mignolo, pone al descubierto la relación entre espacio y pensamiento, y hace referencia a aquellos argumentos justificados por el origen de su enunciación antes que por el enunciado en sí. En este sentido, el meridiano sería una lucha por la legitimación y apropiación de un espacio geocultural por parte de los hispanoamericanos, justificadas por criterios geográficos. Entendida así, y no como un fenómeno puntual de 1927, podremos dilucidar cómo continúa la polémica tras la clausura de Martín Fierro. Veremos, pues, que las transformaciones de las formaciones discursivas del campo literario permiten el desarrollo de un nacionalismo distinto al anterior cuya consecuencia más clara es la escisión de los exmartinfierristas por razones ideológicas.

La propuesta del trabajo se centra en las relaciones que mantienen las revistas culturales del período comprendido entre 1930 y 1945, en concreto, en sus debates en torno al nacionalismo de corte hispánico. Partimos de una división en el campo periodístico que distingue entre Sur frente a los numerosos periódicos nacionalistas que proliferaron durante esos años. Nos detendremos en el enfrentamiento ideológico de la revista de Ocampo con Criterio, pues ambas comparten colaboradores comunes, pero posiciones políticas muy distantes. Veremos cómo en Sur se produce un giro del meridiano que mira más a Europa que a su país, debido al peligro que supone el nacionalismo entre los intelectuales liberales afines a la revista. Entre los nacionalistas, por el contrario, existe una vertiente de pensamiento que vincula lo nacional con la identidad hispano-católica, en oposición a la tradición anglosajona y protestante. Dichos intelectuales dan una vuelta de tuerca al meridiano de Martín Fierro, aceptando el abolengo hispánico como rasgo identitario. Esto último da como resultado el ideologema denominado "mito de la nación católica", una patria utópica de dichas características que verá en el peronismo la esperanza de su realización. En suma, nos centraremos en las redes de intercambio dialógico en la prensa nacional entre 1930 y 1945 para dilucidar las configuraciones culturales e ideológicas que caracterizaron la Década Infame.

\section{El meridiano como red coyuntural de la identidad hispanoamericana}

Antes de hablar de movimiento o generación, Claudio Maíz (2011) se decanta por la noción de "red" para explicar el modernismo hispanoamericano. La red consiste en una circulación continua de convenciones culturales que condicionan el espacio propicio para que una determinada idea se imponga o se vuelva hegemónica. A diferencia de un sistema, sigue Maíz, la red toma cuestiones interrelacionadas por medio de la transferencia de información entre sus agentes implicados -epistolario, prensa, dedicatorias, paratextos, etc.- La red no es sinónimo de 
campo (Bourdieu), pues aquella puede atravesar diversos campos de distinta naturaleza intelectual, cultural, político, etc.- Maíz concibe las redes como algo dinámico, siempre en proceso de creación, de ahí la dificultad de su delimitación. En este sentido, la red es un "espacio matricial y virtual", en tanto crea las condiciones discursivas necesarias para que se genere un cambio en el campo social: “...los «espacios matriciales» están operando anticipadamente para que llegue a producirse el fenómeno de cambio. Dicho de otro modo, la red de los modernistas ha creado las condiciones necesarias para la admisión de la novedad estética” (Maíz, 2011, p. 38). El concepto de red es eficiente para indagar en las formaciones discursivas de una época, pero marginando la cuestión generacional, ya que en una red pueden intervenir individuos de distintas edades quienes, ni siquiera, deben compartir el mismo espacio geográfico. El requisito necesario es, más bien, el intercambio de ideas materializadas en textos, de los cuales el investigador pueda sacar conclusiones generales de un fenómeno intelectual, cultural, estético, político, etc. Tal estudio arqueológico propone y lleva a cabo Maíz en relación al modernismo, concebido como "actor-red", noción intermedia entre autor y colectividad; de esta manera, el conjunto de actores que participan en una red devienen actor-red, término heterogéneo que abarca diversidad de ideas que pueden, incluso, contradecirse entre sí. Lo que sí comparten es el debate en torno al/los mismo/s tópico/s que, en el caso de los modernistas, implicó la búsqueda de una definición del arte, la delimitación de la función del artista en la sociedad, y el establecimiento de una literatura hispanoamericana independiente de la europea.

La propuesta de Maíz conecta directamente con la perspectiva sociocrítica, un acercamiento metodológico al texto/discurso literario influido por la teoría de campos de Bourdieu. La sociocrítica concibe la sociedad como sistema de campos vinculados a partir de configuraciones discursivas interrelacionadas, es decir, esas redes descritas por Maíz. A partir de los años setenta, la sociocrítica ha considerado ese maridaje discursivo como objeto de su estudio $^{2}$. La sociocrítica define todo texto como "producto inacabado" que forma parte del ideario de una sociedad (Cros, 2009, pp.111-112). En este sentido, no solo la prensa y las cartas deben ser material de estudio para la descripción de una red, sino también toda obra literaria o no literaria que conecte con cuestiones centrales de la misma. La red se asimila, por tanto, al concepto de "sociograma" de Claude Duchet (1979), un espacio vincular entre textos/discursos y su contexto social; el sociograma no es tampoco sinónimo de campo pues, como las redes, abarca diversos campos sociales que se conectan mediante esa intercomunicación interdiscursiva.

Como explica Bourdieu, los actores que pertenecen al campo intelectual buscan adquirir el mayor grado de capital -económico, material, simbólico y/o cultural- para liderar el criterio de legitimidad ideológica del mismo. Consiste en una lucha pasiva por establecer la hegemonía de una época, es decir, el discurso oficial que condiciona sus configuraciones ideológicas. En ocasiones, la descripción de dicho proceso es difícil de delimitar pues en él intervienen numerosos factores - políticos, ideológicos, culturales, económicos, etc.-, ideas que cristalizan y convergen en textos periodísticos, literarios, discursos políticos, cartas, etc. El campo periodístico es un espacio propicio para describir ese fenómeno pues condensa y pone al descubierto las ideas hegemónicas y contra-hegemónicas de una sociedad. Las revistas hacen circular e importan novedades de una nación o entre distintas naciones, y son un espacio de discusión acerca de la actualidad, dando a conocer las innovaciones del campo intelectual. Por ello, resulta

${ }^{2}$ En Sociocrítica. Prácticas textuales. Cultura de fronteras (1991) M.-Pierrette Malcuzynski reúne una serie de estudios en torno a la sociocrítica. El hispanista francés, Edmond Cros, ha sido uno de los máximos exponentes de este método al aplicarlo en obras como El Lazarillo, El Libro de Buen Amor, La hora de todos, entre otros. 
imprescindible el acercamiento a la prensa más representativa de un período determinado para sacar a la luz las redes de esa sociedad en cuestión, aunando los aspectos políticos, culturales, ideológicos y sociales más significativos.

A partir de lo expuesto, el presente trabajo se propone delinear la evolución del campo intelectual y cultural del período conocido como Década Infame (1930-1943) de la historia argentina. El fin último consiste en explicar los cambios operados en el terreno literario, su evolución respecto a la década anterior y los nuevos cauces que preparan el camino hacia la posterior. Para ello, nos serviremos del concepto "estructura de sentimiento", acuñado por Raymond Williams, que alude a la cultura de un período, "[...] el resultado vital específico de todos los elementos de [su] organización general", pues pone al descubierto la expresión de una etapa histórica (Williams, 2003, p.57). Cada generación, agrega el crítico, se consolida en torno a una estructura de sentimiento determinada (2003, p.58); consiste en una “...hipótesis cultural derivada de los intentos por comprender tales elementos y sus conexiones en una generación o un período" (Williams, 1980, p.155). Dicha noción explicaría, en el campo literario, las manifestaciones artísticas predilectas de una etapa específica, permitiendo una doble perspectiva de ida y vuelta: explicar sus condiciones históricas mediante la circulación de textos $\mathrm{y}$, a su vez, esclarecer las situaciones contextuales por las cuales se genera un discurso concreto en una sociedad y época determinadas.

Hemos escogido la polémica del meridiano intelectual como eje nuclear de nuestra propuesta debido a la dependencia constante que el campo cultural hispanoamericano mantiene con Europa. En otras palabras, nos adherimos a la sugerencia de Sánchez acerca de que la polémica no se reduce al debate de 1927 sino que esa discusión es una red coyuntural que proyecta una cuestión más general de la intelectualidad hispanoamericana desde la emancipación del continente. Como explica Maíz, el código matriz de toda red posee dos planos: uno endógeno y otro exógeno. En el modernismo, el endógeno abarca las cuestiones internas del movimiento en torno a la modernización cultural hispanoamericana, mientras que el exógeno pone de manifiesto su relación de dependencia/independencia con Europa. Un acercamiento a la obra poética de Rubén Darío, por ejemplo, vislumbra un cambio significativo en el plano exógeno del modernismo; la galofilia de Azul... (1888), cuyo modelo cultural y estético estaba en París, se debía a un mayor sentimiento hispánico presente en Cantos de vida y esperanza (1905). Esa transformación sutil entre un texto y otro proyecta un cambio general en las condiciones discursivas hispanoamericanas creadas por el arielismo, entendido este último como el primer giro meridional de los intelectuales con respecto a España. La amenaza de un nuevo enemigo, el imperio anglosajón, aleja a los intelectuales de ese anti-hispanismo generado por las emancipaciones. Tal viraje óptico se traduce de distintos modos en cada país hispanoamericano, pero ninguno de ellos se mantiene indiferente al debate en cuestión. Nosotros nos centraremos en la proyección de esta problemática en el período que sigue a la polémica del meridiano en Argentina (1930-1945) a partir de la prensa.

Ese cambio de perspectiva que apuntamos con respecto a la obra de Darío atiende a un proceso mayor del establecimiento de la "patria intelectual iberoamericana", cuyo origen y configuración es explicado por Maíz en "Teoría y práctica de la «patria intelectual»" (2008). Definido como espacio utópico a alcanzar, la Patria Intelectual es un ideologema creado por las redes intelectuales hispanoamericanas entre quienes destacan Rubén Darío, José Martí, Enrique Rodó, Manuel Ugarte, José Vasconcelos y Henríquez Ureña. Es, en palabras de Maíz, una "figura de la imaginación del intelectual moderno" desarrollada entre 1898-1920 (2008, p.182). Se define por oposición tanto a la República Mundial de las Letras (París) como al imperio anglosajón. 
Pero, aclara Maíz, la Patria Intelectual no se asimila a la ciudad letrada de Ángel Rama pues mantiene o intenta mantenerse al margen del poder, y posee una relación ambivalente entre su autonomía e independencia estatal. Asimismo, no es una noción unívoca pero sí proyecta los vínculos culturales entre los propios hispanoamericanos, y entre ellos y los europeos. En términos espaciales, en la Patria Intelectual converge la unión continental -"nuestra América"- con las apetencias nacionalistas de cada país americano. Dicha unidad se logra, sobre todo, a partir de la lengua como argumento central ${ }^{3}$ :

La patria intelectual se asienta, por un lado, en el conglomerado geo-cultural en que la lengua es un instrumento de comunicación e interacción, por otro, en algunas mediaciones que permiten la acción lingüística, como por ejemplo, los epistolarios y las publicaciones periódicas. En el cruce de esos factores se producen nuevas representaciones del intercambio cultural, tanto como la configuración de nuevas nociones respecto del rol del intelectual, la nacionalidad como medida de la producción literaria, los centros de poder simbólico, entre otros puntos. (Maíz, 2008, p.177)

Según Maíz, este concepto iniciaría un declive a partir de 1920 porque es un fenómeno directamente ligado al modernismo, cuya hegemonía empieza a decaer alrededor de esa fecha. Los años veinte significan el establecimiento de la vanguardia como movimiento artístico -el martinfierrismo, por ejemplo- y forma de pensamiento -ruptura con todo lo anterior, impulso bélico como negación de normas y reglas estéticas, política beligerante, etc.- Las vanguardias hispanoamericanas muestran la paradoja de considerarse cosmopolitas en la teoría, mientras que en la práctica responden al nacionalismo propio de los países emergentes donde se desarrollan. Así, en el manifiesto martinfierrista los miembros se oponen a "...la ridícula necesidad de fundamentar [un] nacionalismo intelectual", al tiempo que abogan por esa Patria Intelectual creada por el modernismo:

"MARTÍN FIERRO” cree en la importancia del aporte intelectual de América, previo tijeretazo a todo cordón umbilical. Acentuar y generalizar, a las demás manifestaciones intelectuales, el movimiento de independencia iniciado, en el idioma, por Rubén Darío, no significa, empero, finjamos desconocer que todas las mañanas nos servimos de un dentífrico sueco, de unas tohallas de Francia y de un jabón inglés (Martín Fierro, ${ }^{\circ} 4$, 1924).

La cita deja entrever un homenaje de la vanguardia a esa generación literaria anterior con que pretende romper relaciones. Si bien es cierto que aclaran su hipotética universalidad, la influencia de la Patria Intelectual es explícita en el manifiesto. En este sentido, el párrafo citado funciona como bisagra que, de alguna manera, clausura el modernismo y su consecuente idea de Patria Intelectual, pues el concepto ya no funciona en esta nueva época. No obstante, el cosmopolitismo no es la formación discursiva que lo reemplaza como podría esperarse de todo movimiento de vanguardia. Durante su período de vigencia, la revista Martín Fierro homenajea, sobre todo, a artistas argentinos y divulga textos de creación interna. La polémica del meridiano

${ }^{3}$ En un estudio reciente, Fernando Degiovanni (2018) también se centró en la cuestión de la lengua respecto a la creación del "latinoamericanismo" como disciplina vernácula, centrándose, sobre todo, en la figura de Manuel Ugarte. 
sería, entonces, el punto álgido del nacionalismo que recorre implícitamente sus páginas hasta su cierre inmediato. En los apartados que siguen, se describirá la evolución de las dos redes expuestas, la Patria Intelectual y la polémica del meridiano, en el período de 1930 a 1945 de la cultura argentina.

\section{Década Infame, el camino hacia el peronismo}

La Década Infame, debe su nombre al periodista José Luis Torres quien, en 1945 denomina así a un paréntesis histórico entre el gobierno peronista y los años veinte, un hiato caracterizado por una inestabilidad política y económica a partir del golpe de Estado del general J. F. Uriburu (1930). El gobierno de facto pone fin al período de desarrollo económico e industrial anterior y la desestabilización del país se hace notar en todos los campos de la sociedad, sobre todo, el intelectual. La Década Infame significó el cuestionamiento del intervencionismo estatal, el progresivo declive de la hegemonía agraria burguesa, el cuestionamiento de la democracia y, en consecuencia, la relectura de la Ley Sáenz Peña y la Reforma universitaria ${ }^{4}$ :

El intervencionismo en sus versiones fascista y nacionalsocialista combinaron Estados fuertemente ideologizados con grandes intereses económicos a los que buscaban someter [...]. En nuestro país, la coincidencia entre políticos y empresarios que originó el intervencionismo estatal, abrió los aparatos de regulación a los representantes de las entidades corporativas. (Sidicaro, 1998, p.32)

Torres indica que el año de 1943 clausuraría la Década Infame al iniciarse la hegemonía de industrialización nacional, en detrimento del liberalismo. Sin embargo, el período de 19431945 es aún un hiato en transición en que las configuraciones ideológicas no están aún consolidadas y cristalizan a partir de la ascensión de Perón al poder. Al intentar describir este período, ha de tenerse en cuenta el papel que jugó el revisionismo que intelectuales de la década posterior hicieron del mismo -empezando por José Luis Torres-, cuya división dicotómica entre aliados o enemigos del peronismo condiciona la perspectiva en que se entendieron los treinta. La Década Infame se caracterizó por una pluralidad ideológica no solo entre la intelectualidad, sino dentro de la propia izquierda, del nacionalismo, del liberalismo y del catolicismo, diversidad que inevitablemente dificulta su sistematización. Son años de constantes transformaciones en que muchos intelectuales cambian su modo de pensar o su postura política debido a una desconfianza hacia los posibles rumbos que tomará el país. Los acontecimientos en Europa -la guerra civil española, la emergencia de los fascismos, etc.- provocan una inquietud constante que los intelectuales dejan traslucir en la prensa. Asimismo, el Crac del 29 generó una atmósfera de pesimismo económico entre la mayoría de los países occidentales, y llevó a cuestionar la seguridad en el progreso, la industria y la organización nacional en general. En cada país, la crisis

\footnotetext{
${ }^{4}$ Por ejemplo, desde las páginas de Criterio, Juan Emiliano Carulla y Ernesto Palacio, se oponen a la Reforma y apoyan la dictadura de Uriburuen: "La ideología de la reforma universitaria" (Palacio, I/19, 1928, pp.39-40) y "Las tendencias demagógicas en la reforma universitaria” (Carulla, 25/I, 1928, pp.233-234).
} 
se profundizó o se estabilizó según sus circunstancias concretas. A partir de ello, se replantea el intervencionismo del Estado en la vida social ${ }^{5}$.

Una de las consecuencias de la inestabilidad nacional se traduce en la revisión historiográfica de esos años. La historia se presenta como un texto malinterpretado a la espera de una lectura óptima alejada de la hegemonía liberal, lo que pone de manifiesto que la crisis fue económica, política pero, sobre todo, ideológica. El revisionismo se institucionalizó en el grupo FORJA (Fuerza de Orientación Radical de la Joven Argentina, 1935), cuyos ideales nacionalistas los impulsan a contrarrestar el punto de vista de Historia de San Martín y de la Emancipación Sudamericana, escrito por Bartolomé Mitre en el siglo anterior. La revisión de la historia posee, entre otros, el fin de crear una unidad patriótica, como recuerda Ernesto Palacio en La historia falsificada (1939) "No hay patria sin historia, que es la conciencia del propio ser. No hay nacionalidad sin una idea [...] sobre su vocación y su destino [...] Necesitamos con urgencia una historia argentina escrita libremente" (1960, pp.14-18). FORJA tiene como modelo la presidencia de Yrigoyen ${ }^{6}$ por respetar de manera fiel el espíritu de la Reforma universitaria de 1918 mediante su postura antiimperialista sobre una base organizada en las masas populares, pero alejada de la lucha de clases marxista. FORJA hizo uso de distintos modos de difusión de sus ideas-volantes, manifiestos, panfletos etc.-, entre los cuales destaca Cuadernos de FORJA, revista publicada entre 1936 y 1942. El movimiento se diluye en la significativa fecha del 17 de octubre en 1945 cuando Perón accede al poder presidencial, poniendo al descubierto la estrecha relación ideológica que lo unía al peronismo - para algunos críticos, FORJA sería su antecedente, aunque no todos sus miembros se adhirieron al movimiento ${ }^{7}$. . Durante los años cincuenta, Juan José Sebreli desmitifica algunas de las obras escritas con estos propósitos, cuyo nacionalismo superficial, explica, no está sustentado en hechos históricos reales como sus autores aseveran ${ }^{8}$. No obstante, como todas las posturas de la época, tampoco el revisionismo tuvo una visión homogénea. En concreto, la relectura del rosismo es clave, pues algunos interpretan la Federación como modelo de gobierno por su capacidad de conducir a las masas y el nacionalismo del líder ${ }^{9}$. Uno de sus defensores fue Manuel Gálvez, quien reforzó con tenacidad el paralelismo entre Rosas e Yrigoyen - una equivalencia a la cual se le añadirá luego la figura de Perón-. Así, al tiempo que Gálvez redacta las biografías de Yrigoyen y de Rosas, creando una imagen mitificada del rosismo, otro nacionalista, Rodolfo Irastuza, menosprecia la figura de Yrigoyen, desestima el gobierno rosista y, posteriormente, no se asocia al peronismo, pero admite la inutilidad del Golpe del 30 -en "La introducción al fascismo", 12/11/1933)— ${ }^{10}$.

${ }^{5}$ En "El campo intelectual y cultural argentino de la Época Infame (1929-1945)" (2019) hemos desarrollado esa radiografía de la época señalada.

${ }^{6}$ Existía una oposición entre Alvear e Yrigoyen, como se observa en el volante de junio de 1939 "¿Quién perdona a quién? ¿Alvear a Yrigoyen o Yrigoyen a Alvear?” (Jauretche, 2015, pp.94-97).

${ }^{7}$ Aníbal Ford define FORJA como "mitología de un grupo [...] que iba a ser uno de los nexos fuertes entre los dos grandes movimientos de masas de la Argentina contemporánea: yrigoyenismo y peronismo" (2006, p.104).

${ }^{8}$ Los artículos principales son: "Sobre La seducción de la barbarie", Sur, 228, 1954; "Jorge Abelardo Ramos: Crisis y resurrección de la literatura argentina", Sur, 230, 1954; y "Ernesto Palacio: Historia de la Argentina. 15151938 ", Sur, 235, 1955.

${ }^{9}$ Un ejemplo del interés creciente que suscita Rosas se halla en una encuesta sobre su figura en Crítica el 24/07/1927.

${ }^{10}$ Citado en Segovia: "Como balance de la situación política puede decirse que hemos gastado en un lustro los dos grandes recursos de la democracia plebiscitaria y de la dictadura militar, sin obtener ningún resultado plausible. Estamos de nuevo bajo la férula del liberalismo, de un liberalismo obcecado y trasnochado, y tenemos que encontrar el medio de librarnos de él” (2006, p.45). 


\section{La revista Sur: un meridiano que mira a Europa}

Como toda crisis, sus efectos se empiezan notar durante los años anteriores a su eclosión; por ello, la sensación de inminencia de una catástrofe futura condiciona, en el campo literario, la clausura de la revista de vanguardia más importante del país, Martín Fierro en 1927. Como explica Horacio Salas, las problemáticas políticas y la división ideológica entre sus miembros contradicen sus intereses de conservar su autonomía. Sus colaboradores no admiten la posibilidad de mantenerse al margen de la nueva situación que vive la nación. Por este motivo, los irigoyenistas se alejan de la revista y determinan su cierre definitivo:

Pero el caso es que Martín Fierro protestó de esa actitud política de Borges y otros amigos, declarando que ese periódico, y el grupo literario de su nombre, nada tienen que ver con la adhesión irigoyenista, y se mantienen rigurosamente al margen de la política. Por su parte, Borges y los otros han respondido a Martín Fierro en forma violenta, deslizándose del grupo y del periódico. Se ha roto, pues, el frente "vanguardista" por obra de la política. (Schwartz, 1991, p.475)

Uno de los factores que denotan el impacto de la crisis en el campo literario son las diferencias entre la revista dominante de los veinte, Martín Fierro, y la que adquiere el papel central de la década del treinta, Sur. Además de algunos exmiembros de la primera, en la segunda colaboraron nuevas figuras como C. A. Erro, Eduardo Mallea, Ernesto Sábato, Adolfo Bioy Casares, José Bianco, y personalidades foráneas: Alfonso Reyes, Ortega y Gasset, Gómez de la Serna, Pablo Neruda, etc. La heterogeneidad de prácticas estéticas, tendencias ideológicas, origen y edades hace imposible hablar de generación literaria en el caso de Sur, una homogeneidad que sí había alcanzado deliberadamente Martín Fierro. No estaba entre los intereses de Victoria Ocampo conformar esa unión principalmente por dos razones: Martín Fierro responde a la tendencia gremialista de todo movimiento de vanguardia y su breve duración permite una uniformidad incomparable a los cambios que sufriera Sur a lo largo de su trayectoria. En segundo lugar, las tres polémicas que se desataron entre las páginas de Martín Fierro favorecieron una identidad colectiva; además de la ya referida polémica del meridiano, su hipotética oposición a Boedo y a la generación anterior intensifican esa unidad. Sur, en cambio, sufre cierta divergencia interna entre sus colaboradores y, más importante, carece de un enemigo concreto en el campo literario, aunque sí tiene adversarios en otros ámbitos. Como veremos, sus miembros sostienen debates ideológicos o políticos con distintos intelectuales e, incluso, en sus discusiones participan figuras extranjeras. Sur interviene en controversias ideológicas de una época marcada por la crisis, dejando de lado los intereses de innovación lúdica y vanguardista de Martín Fierro. A diferencia de la revista de Evar Méndez, Sur no era únicamente literaria, pues en sus páginas se deliberan cuestiones políticas, ideológicas, filosóficas, históricas, asumiendo así el papel de perfilar el espacio de los intelectuales en la sociedad, en concreto, en el número titulado "Defensa de la inteligencia" $(46,1938)^{11}$. Ese volumen de Sur es significativo en cuanto que demuestra cómo el campo cultural se aproxima al político y al intelectual, un acercamiento motivado por las

\footnotetext{
${ }^{11}$ Esta búsqueda por definir la función del intelectual en la sociedad no es exclusiva de Sur; desde Criterio, Gálvez hace hincapié en la obligación del intelectual a comprometerse con su tiempo histórico, amenazado por la emergencia del socialismo y/o comunismo ("El deber de las clases dirigentes", 194, 1931241-242).
} 
nuevas circunstancias, a diferencia de la autonomía que el campo literario de los veinte había conseguido. En palabras de Martínez Pérsico:

De esta forma, la pretérita apoliticidad literaria de la vanguardia -en una y otra orilla- se tornará militante: la realidad se filtra lentamente en tonos y temas, dando consistencia a la equívoca bifurcación de la vanguardia en "vanguardia artística" y "vanguardia política". (2012, p.53)

Pasternac distingue entre dos tendencias literarias de Sur: la espiritualista de Mallea, que contrasta al universalismo de Borges y que se impondrá como dominante de la narrativa que se cultiva en los cuarenta (2002, p.207). No obstante, todos poseen como común denominador el rechazo al realismo, por su asimilación al nacionalismo, lo que explica la marginación de algunos autores entre las páginas de Sur. Como apunta irónicamente Jorge Rivera, al marginar a ciertos nombres como Arlt, Quiroga, Lugones, Gálvez, Lynch y Armando Discépolo, Sur se convierte en una "flecha invertida" que mira a Europa ${ }^{12}$. Sin decirlo explícitamente, Rivera indica un cambio del meridiano intelectual de Sur respecto a Martín Fierro.

Uno de los efectos que inciden directamente en el campo cultural de la época es el predominio del ensayo por encima de otros géneros (King, 1989, p.81). El apogeo del texto ensayístico se adapta a los debates en torno a las "graves cuestiones" que viven los intelectuales, como apunta John King ${ }^{13}$. Durante los primeros años de la década, los ensayos indagan sobre asuntos literarios pero las tensiones políticas y ciertos acontecimientos irán desviando la atención hacia otros temas. La Guerra Civil Española y la II Guerra Mundial generan una conmoción colectiva y una serie de polémicas; por ejemplo, los artículos donde Gálvez condena la República Española, como "El catolicismo en España" (Criterio, 1931), fueron atacados por Bianchi y Giusti desde Nosotros (Gálvez, 1962, p.159). Asimismo, estalla un debate acerca de la neutralidad argentina, decretada por Roberto Ortiz, que FORJA apoya según el lema yrigoyenista de "Estamos con todos para el bien de todos" -volante de 1939 "El deber argentino ante la guerra"-14. Por su parte, Victoria Ocampo alza la voz desde su revista en "La guerra" (octubre de 1939) para condenar cualquier tipo de neutralidad.

King alude a "...flaqueza de la oposición a Sur" debido a la ausencia de un antagonista que compita por el capital cultural nacional, una situación que ni siquiera el peronismo posterior pudo revertir con la creación de Sexto Continente (King, 1989: 164). En el terreno político, si bien Sebreli (1997, p.453) alude a un breve y efímero contacto de Ocampo con el fascismo italiano, no hay dudas de que ya en 1937 su postura antinazi y su defensa a la República española y los Aliados de la II Guerra es innegable. Aunque entre los colaboradores de Sur no existe una tónica ideológica unívoca común, sí existen ciertas coincidencias entre ellos, sobre todo, en su oposición a toda modalidad nacionalista. Asimismo, Sur coincide en este aspecto con otras

\footnotetext{
${ }^{12}$ Estas reflexiones se han obtenido de una entrevista inédita del crítico ("Encuesta sobre la revista Sur"), que se encuentra en los archivos del Instituto de Literatura Argentina Ricardo Rojas. Agradezco a Guillermo Korn por su aporte bibliográfico.

${ }^{13}$ Terán también hace alusión a la preeminencia del ensayo: "En esa ensayística de los años treinta, la Argentina es construida como un país que ha perdido el norte y que debe arreglar cuentas con su propia conciencia. [...] ensayos que se preguntan por las razones de esa crisis [...] y que suelen deslizarse hacia temas de identidad nacional" (2008, p.243).

${ }^{14}$ Para un análisis detallado del tema, consultar el estudio de Leonardo Senkman "El nacionalismo y el campo liberal argentinos ante el neutralismo: 1939-1943”.
} 
instituciones del país, como la Sociedad Argentina de Escritores (SADE) y el Colegio Libre de Estudios Superiores (CLES) ${ }^{15}$. Las ideas liberales de Ocampo y del grupo en general se proyectaría en su resistencia a la adhesión a todo partido político “....afirmando que se encontraba por encima y más allá de la política, y reconstruyéndolo en términos eternos y en un nivel puramente cultural" (King, 1989, p.247). La pretendida neutralidad al no definirse ni como izquierda ni como derecha carecía de firmeza pues su oposición a la derecha conservadora era explícita. ¿Se consideraba Sur la izquierda intelectual? Sin duda, su elitismo se pone en evidencia años más tarde cuando Ocampo alude a una "élite futura" de Sur en "La misión del intelectual en la comunidad mundial" (Sur, n²46, 1956). Asimismo, en el número 35 se declara en una nota anónima: "No sabemos lo que es ser una revista de izquierda. No nos interesa la cosa política sino cuando está vinculada a lo espiritual" (1937, p.7). Por tanto, si en los años veinte Boedo se autodenominaba grupo de izquierda por su compromiso social, no es el caso de Sur, juzgada como una revista conservadora por la crítica posterior ${ }^{16}$. Así vemos que las disputas del campo intelectual de los años treinta no se asimilan a las categorías antitética de derecha e izquierda y, en concreto, los miembros de Sur se alejan de esta dicotomía de manera explícita en textos publicados en 1938 bajo el rótulo "Defensa de la inteligencia". Allí se plantean la posición del intelectual en la sociedad, la necesidad de tener su lugar propio con la libertad y el liderazgo para intervenir y dirigir la humanidad. A diferencia de los colaboradores de las revistas de cuño nacionalista, los miembros de Sur carecen de unidad ideológica, cuyo centro encuentran en la misión del intelectual considerado como aquel que posee una capacidad especial para guiar a la sociedad. Por ello, Canal Feijoó destaca el término "inteligencia" como una distinción aristocrática de los intelectuales: “...siendo la inteligencia el mayor bien del hombre [...], no puede extrañar que no sea patrimonio de muchos. Al contrario, como mayor bien que es, es acaso el más reservado" (1938, p.51). Por su parte, Ocampo hace hincapié en la obligada universalidad del intelectual, lo que hace del "intelectual nacionalista" una contradicción en sí misma:

La patria, para él, está en peligro. Porque la patria de un escritor, de un artista, de un pensador, no se limita al pedazo de tierra [...] en que nació. Se extiende a todos los lugares de la tierra en que otros escritores [...] nacieron. Por ese hecho estas tierras son también patrimonio suyo. $(1938$, p.8)

En esa explícita oposición al nacionalismo, Ocampo concibe la identidad como la convergencia de "lo argentino, lo americano y lo europeo" (Sitman, 2003: 238). Ello explica su implicación en asuntos políticos internacionales y la difusión de obras extranjeras ${ }^{17}$, aunque Piglia luego desmiente que Sur liderara dicha labor: “...no comparto la versión según la cual debemos a Sur el conocimiento y la difusión de la mejor literatura extranjera. [...] editores más bien alejados de los círculos "refinados" como Santiago Rueda [...] publicaban en esos años el Ulises y El retrato del artista de Joyce" (1990, p.132).

15 Algunos nombres son: Alejandro Korn, Narciso Laclau, y Roberto Giusti, quienes habían participado de la Reforma universitaria de 1918.

${ }^{16}$ Ver Gramuglio (1986) y Sitman (2003).

${ }^{17}$ Gramuglio: "De la importancia que en este viraje fue adquiriendo en Sur la traducción, desde la condición de país receptor de literaturas extranjeras que es propia de culturas que, como la argentina, no ocupan un lugar dominante en la "república mundial de las letras" [...], esta política cultural, que toma un claro partido entre nacionalismo y cosmopolitismo, resulta congruente con las ideas que expuso Borges en «El escritor argentino y la tradición»" (2010, p.209). 
Alejada del patriotismo que traslucía Martín Fierro ${ }^{18}$, Sur busca erigirse como la revista americanista y cosmopolita. El primer aspecto se proyecta, sobre todo, desde 1935, en las siguientes publicaciones: "El espíritu de Sudamérica" (Le Corbusie 5/12, 1935), "Perspectivas sudamericanas" (Conde de Keyserling, 1/2, 1931), "Un paso de América" (Alfonso Reyes, 1/1, 1931), y de la directora: "El camino de América. Carta a París" (10/68, 1940). La evolución de la revista derivó a una presencia cada vez más creciente de nombres extranjeros y de temas acerca de conflictos internacionales, que llegaron a ocupar el centro de interés hacia finales de la década del treinta, razón por la cual Ramón Doll definió irónicamente a Sur como "bazar de importación" (El pampero, 25 de diciembre de 1939), y Piglia como una "revista de la generación del 80 publicada con 50 años de retraso" (1990, p.132). Así, mientras los nacionalistas ven en su europeísmo una tendencia oligarca y una clara traición a la patria, Sebreli ha leído que el americanismo de la revista "compensaría” su europeísmo: “...la crítica de los nacionalistas [...] olvida que también [...] la revista se mostró muy proclive a interpretaciones de la realidad americana como una excepcionalidad cultural, original y única, determinada por la fatalidad telúrica e inaccesible de la cultura europea" (1997, p.450).

Sin embargo, como indica Sarlo, el americanismo responde al doble fin de explicar América tanto a los mismos americanos como a los europeos, $\mathrm{y}$, en un viaje de ida y vuelta, recibir opiniones y críticas de estos últimos sobre el nuevo continente (1983, p.11).

\section{El meridiano intelectual hispano-católico}

Como es sabido, los años treinta significan el cuestionamiento y replanteamiento de nociones como democracia, nacionalismo, totalitarismo, etc. Ello impulsó la progresiva incursión de los intelectuales nacionalistas al espacio público mediante distintos medios: congresos, manifiestos, asociaciones, comités, corporaciones, academias, etc., por ejemplo, la creación del PEN Club o la organización del Congreso Eucarístico Internacional (Manzoni: 2009, p.548). En un plano general, en esa década todo Occidente experimenta un retorno o relectura de la doctrina cristiana, interpretada a partir de una perspectiva negativa del liberalismo, es decir, desde un punto de vista moral y filosófico (Badiou, 2005, pp.48-49). Es la denominada Revolución Conservadora europea, protagonizada por los franceses como Maritain, Maurras, Mounier, el alemán Spengler, y nacionalistas españoles como Ramiro de Maeztu. Consiste en una revisión crítica al progreso ilustrado y liberal que, desde la Revolución Francesa, llevaría a la sociedad a un declive moral y espiritual que, según ellos, debía estallar. El retorno a un orden espiritual lleva a dichos pensadores a recuperar una filosofía cristiana que se contraponga al liberalismo y al materialismo impuesto en Occidente. Esta idea se traduce, en el caso español e hispanoamericano, en la búsqueda de una unidad hispánica de corte católico.

En Argentina, la presencia de Ramiro de Maeztu como embajador en los años treinta y la divulgación de los filósofos franceses en la prensa incide en la intelectualidad nacional-católica,

${ }^{18}$ Cabe aclarar que la revista de vanguardia no perseguía ese fin de manera explícita pero la gran mayoría de sus textos son de producción interna y la Polémica del Meridiano dejó ver ese nacionalismo que palpitaba de trasfondo. 
como recuerda Gálvez ${ }^{19}$. Pero la traslación de sus ideas no es directa, sino que se filtra por la visión del nacionalismo argentino, cuya heterogeneidad ideológica impide esa unidad inherente a todo nacionalismo. Consiste en un proceso que Horacio Tarcus explica en relación con el romanticismo argentino, también importado de Europa:

El momento de la recepción define la difusión de un cuerpo de ideas a un campo de producción diverso del original desde el punto de vista del sujeto receptor. Es un proceso activo por el cual determinados grupos sociales se sienten interpelados por una teoría producida en otro campo de producción, intentando adaptarla a [...] su propio campo. (Tarcus, 2016, p.73)

Una de las divergencias más importantes que atañen directamente al presente estudio es la división en el seno del campo intelectual respecto a la identidad y tradición. La escisión reside en la delimitación de la identidad argentina y la inclusión/rechazo de la tradición hispánica. "Hispanismo" equivale a la reivindicación de la lengua española, a poder eclesiástico Iglesia Católica, a la defensa de la cultura española en detrimento de la anglosajona, etc. Del lado opuesto se aboga por una identidad universal pero que margina a España con un doble fin: continuar la labor de independencia cultural iniciada en el modernismo y, a su vez, contraponerse a los ideales hispanistas de los nacionalistas. Su galofilia es una reacción contra la galofobia, continuando la vía de pensamiento marcada por Sarmiento en el XIX al colocar a Francia como modelo civilizador y a España como la barbarie.

El catolicismo se vio como un medio de negación del liberalismo y un intermedio entre el individualismo y el comunismo, defendiendo un orden jerárquico de la sociedad. Esta es la causa por la cual el peronismo se sustenta, en parte, en la doctrina católica a partir de su discurso de la "tercera vía" alternativa al fascismo y comunismo. Ya Maritain aludía a esa idea de la "tercera posición" peronista en "Con el pueblo de un nuevo humanismo" (1937) al conjugar lo espiritual con lo material en consonancia con su espiriualidad neotomista. El colectivo nacionalista argentino de los años treinta es heterogéneo y se encuentra disgregado en numerosas revistas que Ianini divide en dos corrientes generales: los de derecha publicaban principalmente en La Nueva República $^{20}$ (1927), Baluarte (1932), Bandera Argentina (1932), Crisol (1932), Clarinada (1937), Nuevo Orden (1940) y Nueva Política (1940); y los católicos integristas escribían en torno a revistas más influyentes: Criterio (1928), Número (1930), Sol y Luna (1938) Ortodoxia (1942), entre otros (Ianinni, 2013, p.159). Los intelectuales católicos y nacionalistas de la Década Infame comparten su oposición al liberalismo al considerar que los intereses nacionales no se compaginan con los extranjeros, señalando la apertura del mercado como el mal principal del país.

En 1928 se funda la revista Criterio como la representación del nacionalismo católico que apoya el Golpe de Estado de $1930^{21}$. Dirigida desde 1928 por Dell'Oro Maiani, Criterio surge a

\footnotetext{
${ }^{19}$ Saítta: “...los intelectuales nacionalistas adquirieron una visibilidad y una gran incidencia en la esfera política inéditos hasta ese entonces [...] basados en la lectura del nacionalista francés Charles Maurras, del alemán Oswald Spengler -principalmente La decadencia de Occidente- y del español Ramiro de Maeztu" (2012, p.248).

${ }^{20}$ La Nueva República, editada hasta 1932, tenía como blanco de crítica la democracia liberal, que consideraban una "utopía abstracta" (Nallim, 2012, p.32), inspirada en el maurrasianismo y basada en el catolicismo integrista y, asimismo, se autocalifican "órgano nacionalista” en el número 3 de 1928.

${ }^{21}$ Entre sus colaboradores más asiduos destacaron Borges, Homero Manzi, F. L. Bernárdez, Fernández Moreno, Leonardo Castellani, Ernesto Palacio, Manuel Gálvez, I. B. Anzoátegui y Julio Irazusta.
} 
partir de los Cursos de Cultura Católica, que aunaban intelectuales y artistas para debatir sobre cultura, política y religión. En su primer número, la revista se presenta como: “...expresión de la voluntad decidida de un grupo numeroso de ciudadanos católicos que, estimulados por las más altas autoridades, aspira a satisfacer adecuadamente la apremiante necesidad de una organización". El apoyo a la dictadura de Uriburu, su oposición a la democracia y la defensa al corporativismo como medio adecuado de organización social, son los principios fundamentales de la revista en sus primeros años. Enrique Osés, por ejemplo, avala el golpe de Estado de Uriburu en "La fuerza y el derecho" (Criterio, n¹49, 1931) y Manuel Gálvez justifica todas las dictaduras de los pueblos latinos con razonamientos telúricos ${ }^{22}$. El corporativismo, como explica Julio Meinvielle en "El Estado gendarme"23, se considera un cauce apropiado para alcanzar un acuerdo entre el pueblo bajo el amparo de un Estado intervencionista, que interceda a favor de todas las clases sociales. No obstante, Gustavo Franceschi, el nuevo dirigente de Criterio a partir de 1932, se muestra reticente al corporativismo sin una previa educación del pueblo antes de su aplicación $^{24}$. Años más tarde, ante la II Guerra Mundial, Franceschi se declara a favor de la democracia orgánica y muestra una clara oposición al liberalismo y totalitarismo, pues este último, afirma “...no puede ser aprobado por la Iglesia” (1940, p.222) y, añade, "[...] ni un católico ni un sacerdote pueden ser liberales" (1940, p.225). Asimismo, expone el clima de inminencia que se vivía por esos años, al percibirse un posible golpe de Estado que se producirá el 4 de junio $1943^{25}$. Miranda Lida señala que su propuesta ante la crisis política del país -crisis que él sitúa en el gobierno de Yrigoyen-, consiste en mantener la autonomía de la Iglesia respecto al Estado y en llevar a cabo una rebelión cristiana, concebida como una revolución moral, sin violencia (2002, p.117). En síntesis, uno de los fines de Criterio era, ante todo, ser partícipe de los debates políticos en auge por aquellos años, es decir, replantearse la organización estatal más oportuna en una época de crisis.

Pero cabe señalar que la revista contó con la colaboración de antiguos martinfierristas que publicaban por un mero interés estético: F. L. Bernárdez, Marechal Jacobo Fijman, Ricardo Molinari, Borges, Homero Manzi, F. L. Bernárdez, Fernández Moreno, Leonardo Castellani, Ernesto Palacio, Manuel Gálvez, I. B. Anzoátegui y Julio Irazusta. Por tanto, el enfrentamiento a Sur es meramente ideológico, y no impidió que algunos escritores participaran en ambos periódicos. La polémica entre ambas revistas se manifestó, no obstante, en una serie de ataques entre Julio Meinvielle, Gustavo Franceschi, Augusto Durelli, Victoria Ocampo y el propio Maritain. La disputa se inicia con un manifiesto publicado en Sur $\left(n^{0} 33,1937\right)$ donde numerosos intelectuales franceses católicos -Maritain y Mounier entre ellos- muestran su descontento hacia el bombardeo en Guernica:

\footnotetext{
${ }^{22}$ En "Interpretación de las dictaduras" (Criterio, 32, 1928), Gálvez afirma que las dictaduras son un fenómeno grecolatino que, en la modernidad, surgen para reestablecer el desorden político provocado por la Revolución Francesa. Y, a continuación, anticipa el inminente Golpe de Uriburu, para él inevitable y necesario: "Pero llegará un día, dentro de algunos años, en que la vida será intolerable en este país. [...] y el socialismo parecerá triunfar. Y entonces tendrá que venir una restauración de la política clásica, es decir, un retorno al orden” (1928, p.44).

23 (Criterio, 149, 1931).

${ }^{24}$ Franceschi: "La revolución, que siempre es el acto de una minoría, no dura si no responde a una necesidad, no solo real sino sentida, consciente en el ánimo de la mayoría” ("Educación y reforma política”, Criterio, 279, 6 de julio de 1933, pp.316-321).

${ }^{25}$ En "Totalitarismo, liberalismo, catolicismo", 662, 7 de noviembre de 1940, pp.221-227.
} 
...está fuera de dudas el hecho de que el pueblo vasco es un pueblo católico y que el culto público no ha sido interrumpido ni un sólo instante en el País Vasco. En estas condiciones, todos los católicos, sin distinción de partidos, están en la obligación de levantar su voz los primeros, para evitar que el mundo sufra la masacre sin piedad de un pueblo cristiano. NADA EXCUSA, CON NADA SE JUSTIFICA, EL BOMBARDEO DE CIUDADES ABIERTAS COMO GUERNICA.

Al mismo tiempo, Maritain publicaba desde Francia -en Nouvelle Revue Français (1 de julio de 1937) - un artículo donde se niega a justificar la guerra civil española y, menos aún, a calificarla de Guerra Santa. Maritain era consciente de la polémica que su opinión causaría entre algunos católicos, como demuestra en una carta inédita dirigida a Victoria Ocampo, a quien le confiesa: "Si es posible, me gustaría que en Buenos Aires mis amigos tengan acceso a este prefacio para discutir mis posiciones" 26 . Su intuición es acertada pues Meinvielle no tarda en responder desde Criterio (493, 1937), justificando las acciones de los nacionalistas para evitar el triunfo del comunismo al afirmar que "lo cristiano es estar franca y sinceramente de parte de la España nacionalista porque es la España Católica". Franceschi se coloca de parte de Meinvielle y acusa al Frente Popular español de ejercer un poder tiránico sobre el pueblo en "El movimiento español y el criterio católico" (Criterio, 15 de julio de 1937):

Y se llega entonces a una conclusión irrefutable: el gobierno del Frente Popular, nacido de una violencia consistente en la falsificación de la voluntad general, y por lo tanto tiránico en su creación, fue igualmente tiránico en el ejercicio del poder, porque no pensó en el bien común de la sociedad sino en su propio provecho. La consecuencia desde el punto de vista católico es clarísima: los sediciosos son los hombres del gobierno, y no quienes intentan libertar de su tiranía a la nación. La justicia acompaña a los revolucionarios.

Maritain, a quien el propio Meinvielle había invitado en numerosas ocasiones para dar conferencias en Buenos Aires, se defiende en "Posiciones" (Criterio, 493, 1937) reprochándole sus ataques y negando ser un "abogado de rojos" que se inclina hacia una "España comunistoide", como Meinvielle había sugerido. En ese mismo número, Franceschi escribe a Maritain una carta abierta recriminándole la publicación de su texto "Con el pueblo de un nuevo humanismo" (Sur, 31, 1937). Para Franceschi “...atacar a los católicos que defienden a sus correligionarios de España" no es tan grave como hacerlo desde las páginas de una revista de izquierdas. De esta manera, descalifica la opinión de Maritain amparándose en el espacio de enunciación de su mensaje, y no tanto en el contenido en sí -recordamos la expresión geopolítica del conocimiento de Mignolo expuesta en la introducción-. Ello obliga a Sur a defenderse y, en una nota editorial anónima de agosto (1937), niega su carácter político y afirma que sigue la tradición nacional de la democracia. Desde "Sur y Criterio" (Sur, 499) Franceschi retoma el tema de discusión y, en lo que atañe a la tradición, afirma de forma tajante que la tradición argentina es "católica" y ha de ser defendida:

${ }^{26}$ Carta en francés inédita manuscrita fechada a 11 de julio de 1937, hallada en el archivo Houghton (Harvard University). Traducción de Teresa Davis. Original: "Si possible, J'aimerais mieux qu'à Buenos Aires mes amis attendent d'avoir en main l'ensemble de cette préface pour discuter mes positions". 
Por lo tanto, si el exceso de inmigración de una raza amenazar con establecer un Estado dentro del Estado o con modificar sustancialmente nuestra herencia tradicional hispana y latina, [...] creo que el Estado [...] tendría derecho y deber de impedir la acción mentada (1937, pp.78-79. Cursiva nuestra)

Los términos destacados ponen al descubierto el eje de implicación argumentativa entre política, religión, cultura y tradición; así, defender España implica necesariamente defender el catolicismo y el nacionalismo en Argentina. Dicho razonamiento es impugnado por Augusto Durelli en dos artículos de Sur: "Carta a la directora de Sur" y "La unidad entre los católicos" $(47,1938)$, donde niega la vinculación obligada entre catolicismo y nacionalismo.

\section{De la patria intelectual americana al mito de la nación católica argentina}

Hasta aquí hemos descrito la gran división entre nacionalistas y antinacionalistas de los intelectuales, representados por Criterio y Sur respectivamente. Las redes de comunicación entre ambas no se redujeron a figuras endógenas del país, sino que, como hemos visto, fueron determinante también cuestiones exógenas, concretamente, la guerra civil española $y$ personalidades extranjeras como Maritain. El enfrentamiento político entre ambas desató explícitamente en sus páginas un intercambio de ideas que pone al descubierto las problemáticas centrales de las redes durante esos años: el nacionalismo y la identidad argentina en relación a Europa. A pesar de la hegemonía cultural de Sur y de compartir colaboradores con revistas nacionalistas como Criterio, lo cierto es que la revista de Ocampo no alcanzó la misma legitimidad en relación a las condiciones ideológicas de la época. En otras palabras, el viraje que el país estaba dando en el terreno político se acercaba a un nacionalismo que cristaliza luego en el peronismo. El proceso de creación de un nacionalismo corporativista y personalista que culmina en el peronismo no es un fenómeno meramente político sino, sobre todo, discursivo y cultural. Antes de existir como partido, el peronismo se inició como doctrina cuyos cimientos se hermanan al nacionalismo de corte hispano-católico que describimos. La intelectualidad nacional-católica argentina de los treinta tiende a asimilar la política a la religión, concibiendo el nacionalismo y el catolicismo como homólogas. Se establece así el ideologema del "mito de la nación católica argentina", un vehículo eficaz para crear un sentimiento de unión y de patriotismo ${ }^{27}$. Consiste en un discurso que asimila lo político y lo religioso, de ahí por ejemplo el vocabulario religioso para aludir al líder político como una suerte de nuevo "mesías". Es una red coyuntural residual de la Patria Intelectual, al ser un espacio utópico (mítico) que se busca establecer mediante la recuperación de la tradición hispano-católica. Empleamos el término "residual" de Williams para aludir a todo proceso cultural que no emerge a partir de la ruptura, sino que posee elementos rastreables en el pasado:

Lo residual, por definición, ha sido formado efectivamente en el pasado, pero todavía se halla en actividad dentro del proceso cultural; [...] puede presentar una relación alternativa o incluso de oposición respecto a la cultura dominante, de la manifestación

\footnotetext{
${ }^{27}$ Para un análisis más detallado del tema, consultar Perón y el mito de la nación católica de Loris Zanatta y El mito de la Argentina laica. Catolicismo, político y Estado de Fortunato Mallimaci.
} 
activa de lo residual [...] que ha sido total o ampliamente incorporado a la cultura dominante. (1988, p.144)

No obstante, las diferencias saltan a la vista: el americanismo de la Patria Intelectual deviene un nacionalismo acérrimo que aleja ese mito del resto del continente americano y lo reduce únicamente a la nación argentina. Dicha recuperación de la tradición hispano-católica se institucionaliza, por ejemplo, en el Congreso Eucarístico Internacional (1934) realizado en Buenos Aires, una prueba evidente de la fuerza y poder del clero en el país. Pero, sobre todo, el mito nacionalista es una suerte de revolución pasiva durante los años treinta, (Gramsci) ya que no es aún una idea hegemónica, pero proyectaba ya una crisis orgánica en la sociedad que deviene revolución activa en el primer triunfo del alzamiento popular peronista de 1943. En términos de Williams, es un fenómeno cultural que no es reconocido como una forma hasta la revolución de 1943, cuando adquiere su plena trascendencia como estructura social ${ }^{28}$.

El mito es, de alguna manera, una idea de nación en potencia que se crea a partir de las polémicas acerca de la identidad y tradición cultural de la década anterior. Se le denominó "mito" por su acepción atemporal y su concepción telúrica de la identidad como espíritu del pueblo que se conserva intacto a pesar de los obstáculos políticos, económicos, ideológicos, etc. El alejamiento de las teorías comunistas, anarquistas, fascistas, y liberales se traduce en una organización corporativista como ideal político ${ }^{29}$. La sociedad debe responder a una jerarquía natural y alcanzar un estado intermedio entre el individualismo y lo colectivo, guiado por un líder escogido por el pueblo y un Estado intervencionista que no contradiga los derechos individuales. Uno de los textos donde se proyecta el mito de manera explícita por primera vez es la conferencia La comunidad organizada pronunciada por Perón en el marco del Congreso Nacional de Filosofía (Mendoza, 1949). Su retórica mesiánica y romántica se adecua a ese mito nacional aludido en las referencias a un lugar futuro, utópico pero posible, cuya unidad central es el trabajador. El mito fue, por tanto, un modo idóneo de conducir a las masas, un discurso que se imbrica en todos los campos sociales, para adscribirse a él o para negarlo.

\section{Sol y luna}

El revisionismo tiene como fin establecer una tradición hispánica cultural mediante la historiografía, por tanto, estos interesen se plasman en el campo literario que, por esos años, se acerca estrechamente al político ${ }^{30}$. Algunos intelectuales que durante la polémica del meridiano concebían la identidad argentina independiente de España, ahora miran a la Madre Patria como

${ }^{28}$ Williams: "Un fenómeno cultural adquiere su plena significación solo cuando es comprendido como una forma (conocida o conocible) de un proceso cultural general o de una estructura" (1980, p.126).

${ }^{29}$ Zanata: “[...] la depuración doctrinaria de los partidos tradicionales, que en el lenguaje católico de la época aludía a la necesidad de que eliminaran de los propios programas toda huella de liberalismo o socialismo para adecuarse a los caracteres eternos de la nacionalidad. [...] garantizar su moderación y evitar que la radicalización del conflicto político condujera a una solución bonapartista guiada por un caudillo oportunista" (1999, p.38).

${ }^{30}$ En palabras de Ángel Rama: "La fuerza actuante del pasado y su pluralidad de manifestaciones son rasgos que deben destacarse cuando intentamos referirnos a la cultura argentina de la gran crisis que se abre en el año 1930 [...] visto que no solo comporta una remoción social intensa, sino también un amplio debate histórico, el mayor que ha conocido la nacionalidad desde sus orígenes. [...]. Todo lo que en él se ha producido, desde el arte y la literatura hasta las formulaciones políticas, desde las filosofías sociales hasta las morales, está marcado por el confusionismo propio de una edad de crisis" (1979, [s.p.]). 
parte de esa identidad. Los escritores interesados en fomentar la unidad hispanista del país colaboran en las revistas mencionadas, entre la que destaca especialmente Sol y luna (19381943), dirigida por Juan Carlos Goyeneche. La misma proyectaba una estética medievalista, una temática católica y una fuerte fidelidad a la Iglesia y a la Santa Sede como rechazo a los "males" de la modernidad: liberalismo, socialismo, comunismo, imperialismo y laicismo. El fin de Sol y luna es expandir un proyecto político cultural católico-nacionalista similar al de una revista anterior, Número, cuya pervivencia fue fugaz ${ }^{31}$. En el número 17 de esta última, Mario Pinto señala la necesidad de desvincular el nacionalismo al liberalismo creado por la Revolución de Mayo y asociarlo, en cambio, al sentimiento hispano-católico:

Con los hombres de la revolución de Mayo [...] se trataba de renegar de España y de abominar, por lo tanto, del pasado. [...]. La gran tradición cristiana de este pueblo, comunicada por la España del Siglo de Oro, quedó interrumpida. [...] La idea de patria debe separase pues del contenido que le ha atribuido el liberalismo. [...] solo alcanza la plenitud de sus sentidos si se la refiere a sus principios espirituales. [...] Esta concepción existió en las grandes épocas de la espiritualidad cristiana y en nombre de ella se realizó el descubrimiento de América. [...] Nuestro país ha nacido en el catolicismo, y fuera del catolicismo, muere. (Número 17, 1931, p.2)

En la declaración de intenciones de Sol y luna no se expone explícitamente esa visión hispanista, pero sí de manera alegórica, en cierto sentido:

En los días que corren y en los cuales un obscurecimiento semejante a la noche gravita sobre los principios eternos, [...] Sol y luna, con el doble simbolismo del Sol, que es la luz directa, y la luna, que es la luz reflejada, quiere contribuir a dar testimonio de la luz y afirmar los principios substanciales del orden verdadero, los cuales tienen su final en la causa primera y su reflejo en todo lo creado [...]. Cuando el sol y la luna se miran frente a frente, se produce el claro prodigio de la armonía. [...] Nuestra revista, con el simbolismo de su título, quiere significar una ferviente aspiración a tal orden. (Anónimo, 1938, p.7)

No hay un proyecto político ni religioso directo en las palabras de la nota editorial, sino que su tendencia católico-nacionalista se percibe entre sus restantes números. Entre las publicaciones más representativas de ese interés nacionalista en Sol y luna cabe mencionar "La dialéctica del imperio" de Sánchez Sorondo (1, 1938); "La Iglesia en la «Leyenda Negra hispanoamericana»" de Rómulo Carbia (2, 1939); "La tradición hispanoamericana en nuestra emancipación política" de Federico Ibarguren (3, 1939); y "El almirante" de Ignacio Anzoátegui $(5,1940)$. Su reivindicación hispanista en plena Guerra Civil se interpreta como un apoyo al nacionalismo español y el inminente ascenso de Franco al poder -un ejemplo significativo sería un texto anónimo "Dice el caudillo" (Sol y Luna, 2, 1939)-. Sol y luna publica textos de autores clásicos españoles, como San Juan de la Cruz, ensayos de carácter político o cultural sobre la

${ }^{31}$ En "El grupo Convivio en Número y la definición de un programa estético-artístico del catolicismo argentino" (2015) Niño Amieva explica con detenimiento tal proyecto a través de las manifestaciones artísticas y los textos de crítica literaria publicados en Número. Para profundizar en la fundación y permanencia de la revista, consultar el estudio preliminar de su edición facsimilar de Lucas Adur, Laura Cabezas y Felipe Dondo de 2018. 
tradición hispánica ${ }^{32}$, y obras de creación de Leopoldo Marechal, Julio Meinvielle, Juan Sepich, Octavio Derisi, Atilio Dell' Oro Maini, Juan P. Ramos, Nimio de Anquin, Roberto de Laferrere, Federico Ibarguren, Marcelo Sánchez Sorondo, Hector Sáenz y Quesada y Rómulo Carbia. Debemos añadir los nombres de Borges y Mujica Lainez, quienes publicaron algunas traducciones a pesar su distancia ideológica con la revista.

En el lado opuesto, Sur comienza a decaer a principios de los cuarenta pues su esplendor culminaría, según Gramuglio, hacia 1945 al comenzar una nueva época en el país (2010, p.199). La revista, lejana del discurso corporativista y del mito cristiano-católico, se había centrado en los debates acerca de la II Guerra Mundial, en la posición de Argentina frente a la misma y en el peligro que suponía el fascismo en política. Pero a pesar de su contraposición al discurso hegemónico en política, Sur y sus colaboradores continúan abanderando la esfera literaria del país -Borges, Bioy Casares, José Bianco, Ernesto Sábato, entre otros-. El mito de la nación católica se proyecta en el terreno literario únicamente en la obra de un autor indudablemente polémico, Leopoldo Marechal, exmartinfierrista, nacionalista y católico. Tras participar en la polémica contra el meridiano madrileño -en "A los compañeros de La Gaceta literaria" (Martín Fierro, 44-45, 1927)-, Marechal se acerca al nacionalismo hispano-católico que hemos descrito y, como explica López Saiz (2016), proyecta el mito de la nación católica en el poemario Poemas australes (1937) y en el ensayo Descenso y ascenso del alma por la Belleza -publicado precisamente por la editorial Sol y luna en 1939-.

En este sentido, el mito de la nación católica sería ese espacio matricial y virtual de lo que posteriormente será el peronismo, y que marcará una serie de códigos político-culturales que no se manifiestan de manera explícita hasta los años cuarenta, pero que invaden las formaciones discursivas y literarias de todos los escritores. Consiste en esa estructura de sentimiento, acuñada por Williams, pues tales códigos son "formas y las convenciones", síntomas de que se están operando nuevas experiencias sociales en proceso, y no de manera repentina (Williams, 1980, pp.156-158). Decimos que los códigos son políticos y culturales debido a que, con la llegada del peronismo al poder, la hegemonía nacionalista es ya evidente. Pero también esto tiene consecuencias culturales al ser la cultura una herramienta eficaz para llevar a cabo el revisionismo histórico. De esta manera, se configura una serie de convenciones culturales que poseen connotaciones político-ideológicas evidentes. El ejemplo más ilustrativo sería la dicotomía Martín Fierro frente a Facundo pues las reivindicaciones de uno u otro revelan algo más que categorías estéticas y están vinculadas a la reivindicación del nacionalismo o el liberalismo respectivamente ${ }^{33}$. Las palabras que cierran el final del prólogo de Borges al Facundo, sintetiza lo expuesto: "No diré que el Facundo es el primer libro argentino; las afirmaciones categóricas no son caminos de convicción sino de polémica. Diré que si lo hubiéramos canonizado como nuestro libro ejemplar, otra sería nuestra historia y mejor" (1977, p.139). Aunque el prólogo es posterior a la época a que nos referimos, demuestra que dicha convención continuó vigente durante gran parte del siglo XX.

Pero más fundamental al tema que nos ocupa es la oposición hispanismo frente a otras culturas, especialmente la anglosajona y la francesa, como base de la identidad y tradición argentina. Como vimos en el caso de Sol y luna, la reivindicación de la poesía del Siglo de Oro se traduce en una posición política evidente en su contexto a favor del franquismo. El homenaje a la

\footnotetext{
32 Por ejemplo, "Totalitarismos" de César Pico (Sol y luna, 3, 1939).

${ }^{33}$ Para un examen detallado de la configuración de la antítesis consultar Facundo o Martín Fierro. Los libros que inventaron la Argentina (2015) de Carlos Gamerro.
} 
cultura hispánica por encima de otras deja traslucir ese mito de la nación católica que hemos expuesto, cuyo ejemplo más representativo en los años cuarenta sería Adán Buenosayres (1948) de Marechal. Por el contrario, Borges sigue la línea opuesta y, en este sentido, es especialmente significativo su cuento "Pierre Menard, autor del Quijote" (Sur, 1940), donde se sustituye al autor español por antonomasia por un francés. Como explica González Echeverría, el experimento de Borges consiste en imaginar una "literatura sin nación" (2002, p. 157-158). La conclusión del crítico se deduce de las siguientes palabras del narrador que afirma cómo el Quijote derivó en un mero “...brindis patriótico, de soberbia gramatical, de obscenas ediciones de lujo" (Borges, 1940, p. 54) (cursiva nuestra). Pero será el propio Borges quien declare su explícito descontento contra el nacionalismo y el hispanismo literarios en "El escritor argentino y la tradición" (1952): "Se dice que hay una tradición a la que debemos acogernos los escritores argentinos y que esa tradición es la literatura española (...). La historia argentina puede definirse sin equivocación como un querer apartarse de España" (1981, p. 271). Asimismo, cabe mencionar la evolución que se opera entre sus ensayos Inquisiciones (1925) y Otras inquisiciones (1952) para el tema en cuestión; el proceso que hemos expuesto explica, en parte, lo que distingue ambas obras en relación a la cultura hispánica, cuya presencia es significativamente mayor en el primero ${ }^{34}$.

\section{Conclusiones}

Delimitar una época histórica responde a intereses pedagógicos que, aunque siempre puede ser cuestionado, es un ejercicio eficaz para dilucidar sus características propias. Para dilucidar los rasgos característicos del período entre 1930 y 1945 nos hemos servido de la noción de "red" (Maíz, 2011), que facilita el acercamiento teórico a las relaciones dialógicas materializadas en cartas, prensa, paratextos, etc. Concebida la polémica del meridiano como red coyuntural de la identidad hispanoamericana, hemos descrito cómo evoluciona el debate en la Argentina posterior al año de 1927. Centrándonos en el campo periodístico, hemos trazado una red de comunicación entre Sur y Criterio, como las revistas representativas de dos tendencias de la época: el nacionalismo y el liberalismo anti-nacionalista. Aunque Sur posee la centralidad literaria, la proliferación de periódicos patrióticos da cuenta de cómo el nacionalismo gana terreno en el campo político, hasta volverse hegemónico con la revolución de 1943. Así, frente al universalismo o americanismo abanderado por Sur, revistas como Criterio y Sol y luna abogan por un nacionalismo de cuño hispano-católico, recuperando fuentes arielistas y reivindicando un meridiano hispanoamericano madrileño. Se establecen así una serie de convenciones que se proyectan en las obras literarias, donde toda reivindicación de la cultura hispánica tiene connotaciones ideológicas que la asocian al nacionalismo y al catolicismo, como vimos en la literatura antinacionalista y antihispanista de Borges.

\footnotetext{
${ }^{34}$ Pero la diferencia reside también en su cambio de perspectiva; por ejemplo, si en "Menoscabo y grandeza de Quevedo" (Inquisiciones) elogiaba el conceptismo del escritor español, lo desacredita en "Quevedo" (Otras inquisiciones)
} 


\section{Referencias Bibliográficas}

Adur, L., L. Cabezas y F. Dondo (2018). Estudio preliminar. En La revista Número: 1930-1931 (pp. 1-93). Buenos Aires: Academia Argentina de Letras.

Alemany, C. (1998). La polémica del meridiano intelectual de Hispanoamérica 1927: estudio y textos. Alicante: Universidad.

Anónimo. (1937). Posición de Sur. Sur, 35, 1937, 7-9.

Badiou, A. (2005). El siglo. Buenos Aires: Manantial.

Binns, N. (2014). Argentina y la guerra civil española. La voz de los intelectuales. Madrid: España.

Borges, J. L. (1940). Pierre Menard, autor del Quijote. Sur, 75, 1940.

. (198). El escritor argentino y la tradición. En Discusión (pp. 267-274). Buenos Aires:

Emecé.

. (1957). El escritor argentino y la tradición. En Discusión (pp. 151-162). Buenos Aires:

Emecé.

. (1969). Luna de enfrente y Cuaderno San Martín. Buenos Aires: Emecé.

. (1977). Prólogo a Facundo. En Prólogos, con un prólogo de prólogos (pp. 134-139).

Buenos Aires: Torres Agüero,

. (2012) Inquisiciones/Otras inquisiciones. Buenos Aires: Random House.

Bourdieu, Pierre (1995). Las reglas del arte. Génesis y estructura del campo literario Barcelona: Anagrama.

Canal Feijoó, B. (1938). Inteligencia y órdenes objetivos. Sur, 46, 48-54.

Carulla, J. E. (1928). Las tendencias demagógicas en la reforma universitaria. Criterio, 25, I, 233-234.

Castellani, S. J. (1937). Maritain, hombre de acción, Criterio, 15 de julio de 1937.

Cros, E. (1991). En torno a la interdiscursividad. En M.-Pierrette Malcuzynski (Ed.).

Sociocrítica. Prácticas textuales. Cultura de fronteras (pp. 81-93). Ámsterdam: Atlanta. . (2009). La sociocrítica. Madrid: Arco/Libros.

Davis González, A. (2019). "El campo intelectual y cultural argentino de la Época Infame (19291945)". Artifara, 19, 213-233.

Degiovanni, F. (2018). Vernacular Latin Amerianisms: war, the market, and the making of a discipline. Pittsburgh: University Press.

Duchet, C. (1979). Sociocritique. París: Nathasn.

Ford, A. (2006). Otro modo de ver las cosas: Arturo Jauretche y los forjistas. En El pensamiento alternativo en la Argentina del siglo XX. Tomo II. Oberismo, vanguardia, justicia social (1930-1960) (pp. 101-110). Buenos Aires: Biblos.

Franceschi, G. (1937a). "Sur" y Criterio. Criterio, X, 499, 77-79. . (1937b). Posiciones. Criterio, X, 493, 350-352.

. (1937c). El movimiento español y el criterio católico, Criterio, 15 de julio.

. (1940). Totalitarismo, liberalismo, catolicismo. Criterio, 13, 6, 223-225.

. (1943). Nuevas consideraciones sobre la Revolución. Criterio, 1, 7, 196-200.

Gálvez, M. (1928). Interpretación de las dictaduras. Criterio, 32, 43-44.

. (1962). Recuerdos de la vida literaria III. Entre la novela y la historia. Buenos Aires: Hachette. 
Gamerro, C. (2015). Facundo o Martín Fierro. Los libros que inventaron la Argentina, Buenos Aires: Sudamericana.

Garrigon Lagrange, R. (1938). El tomismo y la filosofía contemporánea. Sol y luna, 1, pp.9-28.

González Echeverría. (2002). Crítica práctica. Práctica crítica. México: Fondo de Cultura Económica.

Gramuglio, M. T. (1986). Sur en la década del treinta: una revista política. Punto de vista: revista de cultura, 28, pp.32-39.

. (1992). La construcción de la imagen. En La escritura argentina (pp. 37-64). Cuyo: Universidad del Litoral.

. (2002). Posiciones, transformaciones y debates en la literatura. En Crisis económica, avance del Estado e incertidumbre politica (1930-1943) (pp. 324-373) Buenos Aires:

Sudamericana. . (2010. Sur. Una minoría cosmopolita en la periferia occidental. En Historia de los intelectuales en América Latina II. Los avatares de la "ciudad letrada" en el siglo XX (pp. 192-210). Buenos Aires: Katz Ediciones.

Halperin Donghi, T. (2004). La Argentina y la tormenta del mundo. Ideas e ideologías entre 1930 y 1945. Buenos Aires: Siglo XXI.

Hernández Arregui, J. J. (2010). La formación de la conciencia nacional, Buenos Aires: Editorial Docencia.

Ianinni, N. S. (2013). Sol y Luna: una revista nacionalista-católica en el contexto de los años '30 y '40. Anuario del Centro de Estudios Históricos "Prof. Carlos S. A. Segreti”, 13, 13, $155-174$.

Jauretche, A. (2015). FORJA y la década infame. Buenos Aires: Corregidor.

King, J. (1989). Sur. Estudio de la revista argentina y de su papel en el desarrollo de una cultura. 1931-1970. México: Fondo de Cultura Económica.

Lida, M. (2002). Iglesia, Sociedad y Estado en el pensamiento de monseñor Franceschi. De la seditio tomista a la "revolución cristiana", Anuario del IHES, 17, 109-123.

López Saiz, B. (2016). Nación católica y tradición clásica en obras de Leopoldo Marechal. Buenos Aires: Corregidor.

Lugones, L. (1998). De Leopoldo Lugones. En Carmen Alemany Bay (ed.) La polémica del meridiano intelectual de Hispanoamérica (1927). Estudios y textos (p. 145). Alicante: Universidad.

Mallimaci, F. (2005). El mito de la Argentina laica. Catolicismo, político y Estado. Buenos Aires: Capital Intelectual.

Maíz, C. (2008). Teoría y práctica de la "patria intelectual”. La comunidad trasatlántica en la conjunción de cartas, revistas y viajes. Literatura y lingüística, 19, 165-193.

. (2011). La eficacia de las redes en la transferencia de bienes simbólicos: el ejemplo del modernismo hispanoamericano. Alpha, 33, 23-41.

Manzoni, C. (2009). Vacilaciones de un rol: los intelectuales en 1936. En N. Jitrik (ed.) Historia crítica de la literatura argentina. VII Rupturas (pp. 541-566). Buenos Aires: Emecé.

Marechal, L. (1925). Retruque a Leopoldo Lugones, Martín Fierro, $26,2$. . (1926) Filípica a Lugones y a otras especies de anteayer, Martín Fierro, 32, 1-2.

Maritain, J. (1937a). Con el pueblo de un nuevo humanismo, Sur, 31, 7-49. . (1937b). Posiciones, Criterio, X, 493, 349. . (1937c). Carta inédita dirigida a Victoria Ocampo, 11 de julio [archivo Houghton].

Maritain, J. et al. (1937). Un manifiesto de los escritores católicos franceses, Sur, 33,111-112. 
Martínez Pérsico, M. (2012). La gloria y la memoria El ultraísmo iberoamericano suivant les traces de Rafael Cansinos Assens. París: ÉditeurBoD.

Meinvielle, J. (1937a). Los desvaríos de Maritain, Criterio, 8 de julio. . (1937b). Contestación a Jacques Maritain, Criterio, 19 de agosto. . (1937c). De la guerra santa. Refutación del artículo de Jacques Maritain aparecido en la Nouvelle Revue Français, Criterio, 19 de agosto.

Mignolo, W. (2001). Introducción. En Walter Mignolo (comp.) Capitalismo y geopolítica del conocimiento. El eurocentrismo y la filosofía de la liberación en el debate intelectual contemporáneo (pp. 9-54). Buenos Aires: Ediciones del Signo.

Mounier, E. (1938). Inteligencia y personalismo. Sur, 46, 38-62.

Nallim, J. (2012). Transformations and Crisis of Liberalism in Argentina, 1930-1955. Pittsburgh: University Press.

Niño Amieva, A. (2015). El grupo Convivio en Número y la definición de un programa estéticoartístico del catolicismo argentino (1930-1931). AdVersus, XII, 28, 69-108.

Ocampo, V. (1938). Con Sarmiento. Sur, 47, 79.

Palacio, E. (1928). La ideología de la reforma universitaria. Criterio, I, 19, 39-40. . (1960). La historia falsificada. Buenos Aires: Editorial A. Peña Lillom.

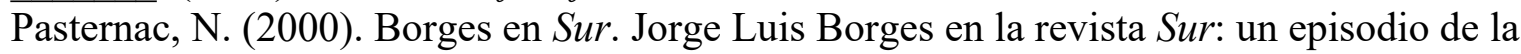
historia literaria. Instituto Tecnológico Autónomo de México, 60-61, 47-71. . (2002). Sur: Una revista en la tormenta. Los años de formación. 1931-1944. Buenos Aires: Paradiso.

Perón, J.D. (2014) La comunidad organizada (1949), Buenos Aires: Biblioteca del Congreso de la Nación.

Piglia, R. (1990). Sobre Sur. En Crítica y ficción (pp. 129-135). Buenos Aires: Siglo Veinte.

Pinto, M. (1931), Consideraciones sobre la Argentina Número, 17, 1-2.

Rama, Á. (1979). Argentina: crisis de una cultura sistémica. INTI: Revista de literatura hispánica, 10. Recuperado de: http://digitalcommons.providence.edu/inti/vol1/iss 10/7

Saítta, Sylvia (2012). La cultura. En Argentina. Tomo 4. 1930-1960. Mirando hacia dentro (pp. 245-300). Madrid: Taurus.

Sánchez, P. (2018). Literaturas en cruce. Estudios sobre contactos literarios entre España y América Latina. Madrid: Verbum.

Sarlo, B. (1983). Los dos ojos de Contorno. Revista Iberoamericana, 125, 797-807.

Schwartz, J. (1991). Las vanguardias latinoamericanas. Textos pragmáticos y críticos. Madrid: Cátedra.

Sebreli, J. J. (1997). Una mujer desdichada: Victoria Ocampo. En Escritos sobre escritos, ciudades bajo ciudades (pp. 435-462). Buenos Aires: Sudamericana. . (2003). Crítica de las ideas políticas argentinas. Los orígenes de la crisis. Buenos Aires: Sudamericana.

Segovia, J. F. (2006). La revolución de 1930. Entre el corporativismo y la partidocracia. Revista de Historia Americana y Argentina, 41, 7-50.

Senkman, L. (s,f).El nacionalismo y el campo liberal argentinos ante el neutralismo: 19391943. Estudios Interdisciplinarios de América Latina y el Caribe, 6,1. Recuperado de: http://www7.tau.ac.il/ojs/index.php/eial/article/view/1203/1231

Sidicaro, R. (1998). Consideraciones sociológicas sobre las relaciones entre el peronismo y la clase obrera en la Argentina, 1943-1955. En Populismo y neopopulismo en América Latina. El problema de la Cenicienta (pp. 153-172). Buenos Aires: Eudeba. 
. (2003). Los tres peronismos. Estado y poder económico. 1946-55/1973-76/1989-99. Buenos Aires: Siglo XXI.

Sitman, R. (2003). Victoria Ocampo y Sur. Entre Europa y América. Buenos Aires: Lumiere. Terán, O. (2008). Historia de las ideas en la Argentina. Diez lecciones iniciales, 1810-1980. Buenos Aires: Siglo XXI.

Torre, J. C. (1998). Interpretando (una vez más) los orígenes del peronismo (pp. 173-196). En Populismo y neopopulismo en América Latina. El problema de la Cenicienta, Buenos Aires: Eudeba.

Williams, R. (1980). Marxismo y literatura. Barcelona: Ediciones Península. . (2003). La larga revolución. Buenos Aires: Nueva Visión.

Zanatta, L. (1999). Perón y el mito de la nación católica. Iglesia y Ejército en los orígenes del peronismo. 1943-1945. Buenos Aires: Sudamericana. 